\title{
Peningkatan Motorik Halus Anak Melalui Proses Pembuatan Minyak Kelapa Di Taman Kanak-Kanak Aisyiah Bustanul Athfal Parit
}

\author{
Dessi Julimarti $^{1^{*}}$ \& Nurhafizah ${ }^{2}$ \\ ${ }^{12}$ Jurusan PG-PAUD, Fakultas Ilmu Pendidikan, Universitas Negeri Padang \\ *Corresponding author, e-mail: dessijulimarti@gmail.com
}

Article Info:

Accepted : 25 Oktober 2019

Published Online: 30 November 2019

\begin{abstract}
Abtract
This study aims to improve the fine motor skills of children in learning through the process of making Coconut Oil in Kindergarten Aisyiyah Bustanul Athfal Parit. The type of research is Classroom Action Research conducted in a cyclical way, namely two cycles each cycle of three meetings. The results showed that fine motor skills in children had not yet developed and continued improvement in the first cycle through the activities of the process of making coconut oil using a variety of tools. In the second cycle achieving optimal results with excellent growing results. Thus it was concluded that the process of making coconut oil can improve the fine motor skills of children in kindergarten Aisyiyah Bustanul Athfal Parit.
\end{abstract}

Keywords: Improved Fine Motor, Coconut Oil Making

This is an open access article distributed under the Creative Commons Attribution License, which permits unrestricted
use, distribution, and reproduction in any medium, provided the original work is properly cited. $\odot 2019$ by author

\section{PENDAHULUAN}

Pendidikan adalah proses pengubahan sikap dan tata laku seseorang atau kelompok orang dalam usaha mendewasakan manusia melalui upaya pengajaran dan pelatihan yang sesuai prosedur pendidikan itu sendiri. Menurut Dewantara (Bapak Pendidikan Nasional Indonesia) menjelaskan tentang pengertian pendidikan yaitu: Pendidikan yaitu tuntutan di dalam hidup tumbuhnya anak-anak, adapun maksudnya, pendidikan yaitu menuntun segala kekuatan kodrat yang ada pada anak-anak itu, agar mereka sebagai manusia dan sebagai anggota masyarakat dapatlah mencapai keselamatan dan kebahagiaan setinggi-tingginya.Menurut UU No. 20 tahun 2003 pengertian Pendidikan adalah sebuah usaha yang di lakukan secara sadar dan terencana untuk mewujudkan suasana belajar dan proses pembelajaran agar peserta didik secara aktif mengembangkan potensi dirinya untuk memiliki kekuatan spiritual keagamaaan, membangun kepribadian, pengendalian diri, kecerdasan, akhlak mulia, serta keterampilan yang diperlukan dirinya, masyarakat, bangsa, dan Negara. Undang-undang inilah yang menjadi dasar berdirinya proses pendidikan yang ada di Negara Indonesia.

Menurut Madyawati (2016:2) Pendidikan anak Usia Dini merupakan jenjang pendidikan sebelum pendidikan dasar yang merupakan suatu upaya yang ditujukan bagi anak sejak lahir sampai usia enam tahun yang dilakukan melalui pemberian ransangan pendidikan untuk membantu pertumbuhan dan perkembangan jasmani dan rohani agar anak memiliki kesiapan dalam memasuki pendidikan lebih lanjut yang diselenggarakan melalui jalur pendidikan formal, nonformal dan informal. Pendidikan di sekolah menjadi tanggung jawab guru. Proses pendidikan seharusnya dapat menjadi bekal untuk diterapkan dalam kehidupan anak di lingkungan masyarakat, Nurhafizah (2018). Guru merupakan tenaga profesioanal yang bertugas merencanakan, melaksanakan, menilai hasil pembelajaran, karena guru sebagai ujung tombak pendidikan sebab secara langsung berupaya mempengaruhi, membina dan mengembangkan peserta didik, guru dituntut untuk memiliki kemampuan dasar yang diperlukan sebagai pendidik, pembimbing dan pengajar dan kemampuan tersebut tercermin pada kompetensi guru. 
Salah satu kemampuan pada anak Taman Kanak-kanak yang berkembang dengan cepat adalah kemampuan fisik dan motoriknya. Perkembangan motorik anak akan dapat terlihat secara jelas melalui berbagai gerakan dan permainan yang dapat mereka lakukan. Secara simultan dan berkesinambungan, aktivitas anak akan dikontrol oleh otak. Otak terus mengolah informasi yang diterima. Bersamaan dengan itu, otak bersama jaringan syaraf akan membentuk sistem syaraf pusat yang mencakup lima pusat kontrol, akan mendiktekan setiap gerak anak. Dalam kaitannya dengan perkembangan motorik anak, perkembangan motorik anak berhubungan dengan perkembangan kemampuan gerak anak. Gerak merupakan unsur utama dalam perkembangan motorik anak.

Menurut Zulkifli (2011:31) motorik halus adalah segala sesuatu yang ada hubungannya dengan gerakan tubuh dalam perkembangan motorik unsur-unsur yang menentukan adalah otot, saraf, dan otak. Ketiga unsur tersebut memiliki peranan secara interaktif positif yang saling berkaitan, menunjang, melengkapi unsur yang lainnya untuk mencapai kondisi motorik yang lebih sempurna.Sedangkan menurut Jamaris (2010:13) motorik halus adalah kemampuan untuk beraktivitas menggerakkan otot-otot halus yang mengkoordinasikan gerakan jari tangan dan mata yang membutuhkan kecermatan yang terdapat dalam kegiatan meremas, memasang dan membuka kancing baju, meronce manik-manik, melipat kertas, menyusun balok dan melukis dengan jari.Menurut Suryana (2016:155), perkembangan keterampilan motorik sangat penting bagi perkembangan selfconcept atau kepribadian anak. Stimulasi yang bisa diberikan untuk mengoptimalkan perkembangan motorik anak adalah dasar-dasar keterampilan menulis (huruf Arab dan Latin) dan menggambar. Perkembangan motorik anak akan lebih teroptimalkan jika lingkungan tempat tumbuh kembang anak mendukung mereka untuk bergerak bebas.

Berdasarkan observasi awal di Taman Kanak-kanak Aisyiyah Bustanul Athfal Parit, ditemukan berbagai fenomena, antara lain: Pertama, banyak anak yang belum mampu memegang pensil dengan benar sehingga mereka menggunakan seluruh jarinya untuk dapat memegang pensil tersebut. Anak juga mengalami kesulitan pada saat pembelajaran yang menuntut keterampilan jari tangan, seperti melipat dan menggunting. Anak belum menunjukkan perkembangan yang baik dalam mewarnai gambar, anak belum lagi menunjukkan perkembangan dalam mengurus dirinya sendiri seperti makan dengan benar, memasang kancing baju, mengikat tali sepatu dan menyisir rambut dengan baik. Kedua, terdapat berbagai macam hal yang menjadi faktor penyebab anak mengalami kesulitan dalam penguasaan motorik halus seperti guru yang kurang kreatif dalam menyampaikan metode dan penyediaan alat peraga dan media pembelajaran, kecenderungan yang dilakukan guru adalah memberikan materi yang kurang variatif. Selain itu, masih terbatasnya media serta sarana dan prasarana yang ada di sekolah, sehingga membuat anak jadi bosan belajar.

Guru berusaha mencari jalan keluar untuk peningkatan motorik halus anak pada Taman Kanak-kanak Aisyiyah Bustanul Athfal Parit dengan mengaplikasikan pembuatan minyak dari buah kelapa mulai proses dari meremas, memeras sampai menjadi santan kemuadian mengaduk sampai menjadi minyak kelapa.Tujuan pembuatan Minyak Kelapa dalam meningkatkan kemampuan motorik halus anak merujuk pada pendapat Sumantri (2005) keterampilan motorik halus adalah pengorganisasian penggunaan sekelompok otot-otot kecil seperti jari-jemari dan tangan yang sering membutuhkan kecermatan dan koordinasi mata dengan tangan, keterampilan yang mencakup pemanfaat dengan alat-alat untuk bekerja dan mengetik, menjahit dan lainlain.Tujuan dari area latihan kehidupan praktis seperti memasak yang terdapat pada artikel yang ditulis oleh Batia (2015:604) mengemukakan bahwa area latihan kehidupan praktis seperti memasak mempunyai kegiatan yang bertujuan menstimulasi dan menguatkan ketiga jari dan pergelangan tangan anak.

\section{METODE}

Jenis Penelitian yang digunakan pada penelitian ini adalah metode Penelitian Tindakan Kelas (PTK) atau Classroom Action Research (CAR). PTK berawal dari persoalan-persoalan yang dihadapi guru di kelas. Hasil penelitiannya dapat dimanfaatkan secara langsung untuk kepentingan peningkatan kualitas kegiatan pembelajaran di kelas atau untuk peningkatan kualitas pembelajaran. Dengan kata lain, PTK dapat ditujukan terutama untuk perbaikan pembelajaran sehingga dapat memecahkan masalah dalam proses belajar dan hasil belajar.

Tujuan penelitian tindakan kelas ini menurut Arikunto (2016: 106-107) adalah untuk perbaikan dan peningkatan layanan profesional pendidik dalam menangani proses belajar di dalam kelas. Tujuan itu dapat dicapai dengan melaukakan tindakan alternatif dalam memecahkan masalah yang dihadapi. Fokus penelitian ini terdapat pada tindakan yang direncanakan oleh guru, yang selanjutnya akan diterapkan pada peserta didik, kemudian dievaluasi apakah berhasil atau tidak. 
Penelitian ini bertempat di Taman Kanak-kanak Aisyiyah Busthanul Atfal Parit Pasaman Barat beralamat di Jorong Pemukiman Baru I Kenagarian Parik Kecamatan Koto Balingka, Kabupaten Pasaman Barat. Sedangkan waktu penelitian ini dilaksanakan pada Semester I Tahun Pelajaran 2019/2020. Subjek penelitian ini adalah anak kelompok B di Taman Kanak-kanak Taman Kanak-kanak Aisyiyah Busthanul Atfal Parit Pasaman Barat tahun pelajaran 2019/2020 dengan jumlah anak sebanyak 16 orang yang terdiri dari 7 orang anak laki-laki dan 9 orang anak perempuan. .dilaksanakan dalam dua siklus sebanyak 3 kali pertemuan. Data yang diperoleh selama proses pembelajaran diolah dengan teknik persentase yang dilakukan oleh Arikunto (2016:170). Hasil pengamatan dinilai untuk setiap pertemuan, berdasarkan jumlah persentase anak yang terlibat dalam aktivitas pembelajaran dengan rumus sebagai berikut:

$$
\mathrm{P}=\frac{\mathrm{F}}{\mathrm{N}} \times 100 \%
$$

Keterangan :

$\mathrm{P} \%=$ Persentase aktivitas

$\mathrm{F} \quad=$ Frekuensi aktivitas yang dilakukan anak

$\mathrm{n}=$ Jumlah anak dalam satu kelas

\section{HASIL PENELITIAN}

Berdasarkan jumlah anak dalam pelaksanaan peningkatan motorik halus melalui proses pembuatan minyak kelapa dimana pada observasi terhadap anak setelah tindakan dilakukan, maka diperoleh kesimpulan bahwa siklus I belum mencapai Kriteria Ketuntasan Minimum (KKM) yaitu sebesar 75\% yang telah ditetapkan dengan demikian peneliti perlu melakukan tindakan penelitian siklus II. Setelah tindakan dilakukan pada siklus II, maka diperoleh kesimpulan bahwa siklus II telah mencapai Kriteria Ketuntasan Minimum (KKM) yang telah ditetapkan. Keberhasilan peningkatan motorik halus anak melalui proses pembuatan minyak kelapa dengan nilai BSB (Berkembang Sangat Baik) dapat dijabarkan sebagai berikut :

Tabel.1 Persentase Hasil Observasi Peningkatan Motorik Halus Anak Melalui Proses Pembuatan Minyak Kelapa pada Kategori BSB (Berkembang Sangat Baik)

\begin{tabular}{llcc}
\hline No & \multicolumn{1}{c}{ Aspek Yang Diamati } & Siklus I & Siklus II \\
\hline 1. & $\begin{array}{l}\text { Anak dapat menuangkan air sesuai takaran pada parutan } \\
\text { kelapa melalui proses pembuatan minyak kelapa }\end{array}$ & $31 \%$ & $87 \%$ \\
2. & $\begin{array}{l}\text { Anak dapat meremas parutan kelapa melalui proses } \\
\text { pembuatan minyak kelapa }\end{array}$ & $25 \%$ & $94 \%$ \\
3. & $\begin{array}{l}\text { Anak dapat menahan tapisan dengan tangan hasil remasan } \\
\text { parutan kelapa melalui proses pembuatan minyak kelapa }\end{array}$ & $19 \%$ & $81 \%$ \\
4. & Anak dapat mengaduk adonan santan menjadi minyak \\
kelapa melalui proses pembuatan minyak kelapa & $19 \%$ & $81 \%$ \\
\hline
\end{tabular}

Berdasarkan tabel di atas persentase hasil observasi peningkatan motorik halus anak melalui proses pembuatan minyak kelapa pada kategori BSB (Berkembang Sangat Baik) pada:

Aspek anak dapat menuangkan air sesuai takaran pada parutan kelapa melalui proses pembuatan minyak kelapa, pada siklus I dengan persentase sebesar 44\% dan mengalami kenaikan menjadi $87 \%$ pada siklus II.Aspek anak dapat meremas parutan kelapa melalui proses pembuatan minyak kelapa, pada siklus I dengan persentase sebesar $25 \%$ dan mengalami kenaikan menjadi $94 \%$ pada siklus II.Aspek anak dapat menahan tapisan dengan tangan hasil remasan parutan kelapa melalui proses pembuatan minyak kelapa, pada siklus I dengan persentase sebesar $19 \%$ dan mengalami kenaikan menjadi $81 \%$ pada siklus II.Aspek anak dapat mengaduk adonan santan menjadi minyak kelapa melalui proses pembuatan minyak kelapa, pada siklus I dengan persentase sebesar $19 \%$ dan mengalami kenaikan menjadi $81 \%$ pada siklus II.Lebih jelasnya dapat dilihat pada grafik dibawah ini : 


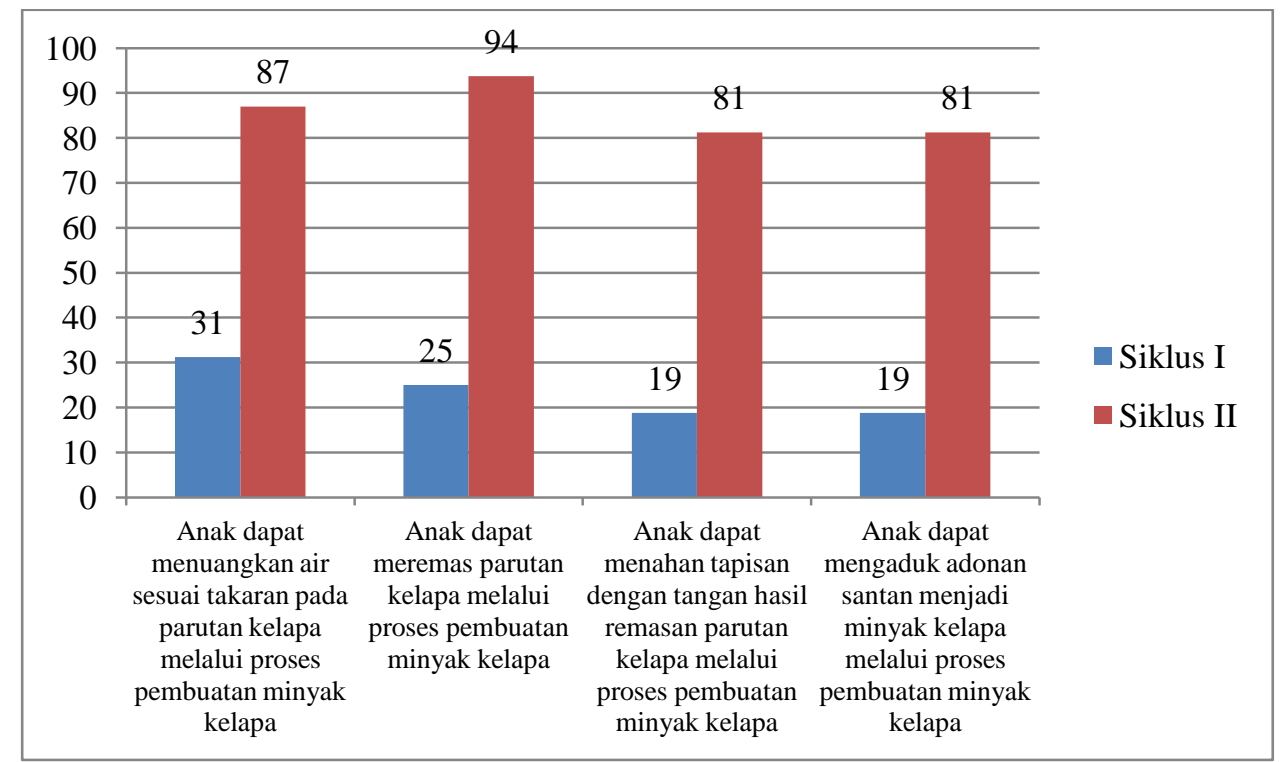

Gambar 1. Persentase Hasil Observasi Peningkatan Motorik Halus Anak Melalui Proses Pembuatan Minyak Kelapa pada Kategori Sangat Baik

\section{PEMBAHASAN}

Berdasarkan data hasil penelitian pengembangan motorik halus melalui proses pembuatan minyak kelapa di Taman Kanak-Kanak Aisyiah Bustanul Athfal Parit. Adapun pembahasan guna untuk memperjelas dan memperdalam kajian dalam penelitian ini.Setelah melihat kondisi awal tentang motorik halus anak di Taman Kanak-Kanak Aisyiah Bustanul Athfal Parit peneliti melakukan tindakan untuk meningkatkan motorik kasar halus melalui proses pembuatan minyak kelapa. Guru merupakan tenaga profesioanal yang bertugas merencanakan, melaksanakan, menilai hasil pembelajaran, karena guru sebagai ujung tombak pendidikan sebab secara langsung berupaya mempengaruhi, membina dan mengembangkan peserta didik, guru dituntut untuk memiliki kemampuan dasar yang diperlukan sebagai pendidik, pembimbing dan pengajar dan kemampuan tersebut tercermin pada kompetensi guru (Delfia dan Nurhafizah, 2019).

Aspek anak dapat menuangkan air sesuai takaran pada parutan kelapa melalui proses pembuatan minyak kelapa, pada siklus I dengan persentase sebesar $44 \%$ dan mengalami kenaikan menjadi $87 \%$ pada siklus II. Perkembangan motorik terbagi dua yaitu: motorik kasar dan motorik halus. Motorik kasar adalah gerakan/aktivitas yang menggunakan otot-otot besar atau bahkan seluruh anggota tubuh. Motorik halus adalah kemampuan yang berhubungan dengan keterampilan fisik yang melibatkan otot-otot kecil. Pengembangan motorik halus dapat dilakukan melalui berbagai kegiatan dalam bermain (Rakimahwati, R, 2014).

Aspek anak dapat meremas parutan kelapa melalui proses pembuatan minyak kelapa, pada siklus I dengan persentase sebesar 25\% dan mengalami kenaikan menjadi $94 \%$ pada siklus II. Melalui kegiatan meremas kemampuan motorik halus anak dapat ditingkatkan karena anak meremas-remaskan jari-jari tangannya supaya adonan menjadi rata. Dari kegiatan tersebut terjadi pengembangan motorik halus anak.Sesuai dengan pernyataan menurut Rakimahwati (2012) menjelaskan pengembangan motorik halus anak ditekankan pada koordinasi gerakan motorik halus, dalam hal ini berkaitan dengan kegiatan meletakkan atau memenag suatu objek dengan menggunakan jari tangan.

Aspek anak dapat menahan tapisan dengan tangan hasil remasan parutan kelapa melalui proses pembuatan minyak kelapa, pada siklus I dengan persentase sebesar 19\% dan mengalami kenaikan menjadi $81 \%$ pada siklus II. Aspek-aspek perkembangan dan kemampuan anak usia dini terdiri dari perkembangan kemampuan fisik. Pada masa ini proses pertumbuhan dan perkembangan dalam berbagai aspek sedang mengalami masa yang cepat dalam rentang perkembangan hidup manusia. Salah satu aspek yang perlu distimulasi di Taman Kanakkanak adalah aspek fisik motorik. Alasan utama aspek motorik menjadi bagian dari sasaran Taman Kanak-kanak karena perkembangan motorik memiliki hubungan yang sangat erat dengan aspek-aspek yang lain. Apabila motorik seorang anak bagus, maka bisa dengan mudah dan lancar melakukan suatu kegiatan atau aktivitas yang menunjang pertumbuhan dan perkembangannya (Rakimahwati, 2018). 
Aspek anak dapat mengaduk adonan santan menjadi minyak kelapa melalui proses pembuatan minyak kelapa, pada siklus I dengan persentase sebesar $19 \%$ dan mengalami kenaikan menjadi $81 \%$ pada siklus II. Suasana belajar yang menyenangkan dengan bermain telah memberikan stimulus yang baik terhadap fungsi otak dalam memproses informasi untuk meningkatkan kemampuan motorik halus. Keberhasilan memberikan rangsangan kepada anak dalam upaya peningkatan kemampuan motorik halus anak dengan memberi penguatan serta pujian kepada anak agar lebih bersemangat dalam bermain. (Yenti, 2019).

Melalui siklus I terlihat perkembangan motorik halus anak melalui proses pembuatan minyak kelapa belum meningkat dengan baik, karena masih banyak anak yang tidak percaya diri dengan kemampuan yang dimilikinya, tingkat keberhasilan anak pada siklus I belum mencapai nilai sangat baik, sedangkan pada siklus II perkembangan motorik kasar anak meningkat dengan BSB (Berkembang Sangat Baik) karena di siklus II ini akan yang memperoleh nilai sudah tidak ada lagi anak yang memperoleh nilai BB (Belum Berkembang), sehingga keberhasilan anak pada aspek ini telah melebihi Kriteria Ketuntasan Minimal (KKM) yaitu 75\%.Berdasarkan uraian di atas dapat disimpulkan penelitian tindakan kelas dengan proses pembuatan minyak kelapa dapat meningkatkan motorik halus anak dan dapat memberikan sumbangan positif terhadap peningkatan pembelajaran.

\section{KESIMPULAN}

Berdasarkan hasil penelitian dan pembahasan yang telah diuraikan pada bab sebelumnya, maka dapat diambil kesimpulan dan saran sebagai berikut : Peningkatan motorik halus anak di Taman Kanak-Kanak Aisyiah Bustanul Athfal Parit perlu dikembangkan, salah satunya adalah proses pembuatan minyak kelapa. Peningkatan motorik halus anak melalui proses pembuatan minyak kelapa dapat berkembang dengan baik apabila didukung dengan sarana dan prasarana belajar di Taman Kanak-kanak serta adanya motivasi dari dalam dan luar diri anak. Metode yang digunakan dalam penelitian ini adalah Penelitian Tindakan Kelas dimana peneliti langsung meneliti anak tentang peningkatan motorik halus anak selama proses belajar berlangsung dan berkolaborasi dengan teman sejawat. Setelah dilaksanakan penelitian pada siklus II terlihat peningkatan indikator keberhasilan dibandingkan dengan siklus I terbukti dari hasil yang diperoleh mengenai peningkatan motorik kasar anak pada masing-masing indikator yang telah ditetapkan maka anak yang mendapatkan nilai Berkembang Sangat Baik (BSB) pada akhir siklus I dengan persentase $31 \%$ dan terus mengalami kenaikan menjadi $87 \%$ pada akhir siklus II ini menandakan bahwa dengan proses pembuatan minyak kelapa dapat meningkatkan motorik halus anak.Berdasarkan kesimpulan di atas, ada beberapa saran yang ingin diuraikan sebagai berikut : Pihak sekolah sebaiknya menyediakan sarana permainan yang dapat meningkatkan motorik halus anak. Hendaknya guru menggunakan berbagai macam metode dalam memberikan kegiatan pembelajaran, dengan begitu anak tidak akan merasa jenuh dalam belajar serta tujuan pembelajaran akan tercapai secara optimal. Diharapkan kepada Dinas Terkait untuk memberikan perhatian yang besar dalam peningkatan motorik halus anak di Taman Kanak-Kanak Aisyiah Bustanul Athfal Parit pada khususnya dan Kecamatan Koto Balingka pada umumnya. Bagi peneliti yang lain diharapkan dapat mengembangkan peningkatan motorik kasar anak melalui metode dan sarana pembelajaran yang lainnya. Bagi pembaca diharapkan dapat menggunakan skripsi ini sebagai sumber ilmu pengetahuan guna menambah wawasan.

\section{DAFTAR RUJUKAN}

Arikunto, Suharsimi. 2016. Penelitian Tindakan Kelas. Jakarta: Bumi Aksara.

Bhatia, Punum, Alan Davis \& Ellen Shamas-Brandt. 2015. Educational Gymnastics: The Effectiveness Of Montessori Practical Life Activities In Developing Fine Motor Skills In Kindergartners. Early Education and Development. DOI: 10.1080/10409289.2015.995454.

Delfia, Eva dan Nurhafizah. 2019. Profesionalisme Guru Pendidikan Anak Usia Dini Dalam Merancang Pembelajaran. Jurnal Pendidikan Tambusai. ISSN: 2614-3097(online). Volume 3 Nomor 2 Tahun 2019.

Jamaris, Martini.2010. Perkembangan Anak Usia TK. Jakarta: UNJ

Madyawati, Lilis. 2016. Strategi Pengembangan Bahasa pada Anak. Jakarta: Kencana.

Nurhafizah. 2018. Pelatihan Pembuatan Media Pembelajaran Anak Usia Dini Menggunakan Bahan Sisa. Jurnal Pendidikan: Early Childhood. E-Issn. 2579-7190 Vol. 2 No. 2b, November 2018

Rakimahwati. 2012. Model Pembelajaran Sambil Bermain pada Pendidikan Anak Usia Dini. Padang: UNP Press.

Rakimahwati, R. .2014. Character Development through Dance Learning in an Early Childhood Setting. Indonesian Journal of Early Childhood Education Studies, 3(2), 102-107.

Rakimahwati. 2018. Pengaruh Kirigami Terhadap Kemampuan Motorik Halus Anak di Taman Kanak-Kanak. Jurnal Obsesi : Jurnal Pendidikan Anak Usia Dini Research \& Learning In Early Childhood Education. Vol 2 No 1 (2018) Page 102 - 110. ISSN 2549-8959 (Media Online). 
Sumantri. 2005. Model Pengembangan Keterampilan Motorik Anak Usia Dini. Jakarta: Depdiknas.

Suryana, Dadan. 2016. Pendidikan Anak Usia Dini; Stimulasi \& Aspek Perkembangan Anak. Jakarta: Kencana. Yenti, Gusni. Farida Mayar. Nenny Mahyuddin. 2019. Peningkatan Kemampuan Motorik Halus MelaluiBermain Kertas Krep Di Taman KanakKanak. Journal of Family, Adult, and Early Childhood Education.Volume 1, Nomor 1, Februari 2019 .DOI: 10.5281/zenodo.2571417

Zulkifli. 2011. Psikologi Perkembangan. Bandung: PT Remaja Rosdakarya 